\title{
GAYA BAHASA DAN NILAI MORAL DALAM KUMPULAN PUISI AYAT-AYAT API KARYA SAPARDI DJOKO DAMONO SEBAGAI BAHAN AJAR SASTRA DI SMA
}

\author{
Iin Indah Saputri, Raheni Suhita, Slamet Mulyono \\ Universitas Sebelas Maret \\ Email: indahiin@student.uns.ac.id
}

\begin{abstract}
Abstrak: Penelitian ini bertujuan untuk mendeskripsikan (1) jenis gaya bahasa; (2) jenis nilai moral; dan (3) relevansi hasil temuan kumpulan puisi Ayat-Ayat Api karya Sapardi Djoko Damono sebagai bahan ajar sastra di sekolah menengah atas. Jenis penelitian ini merupakan penelitian kualitatif dengan menggunakan pendekatan stilistika. Sumber data penelitian yang dilakukan ini adalah dokumen jenis gaya bahasa dan nilai moral dalam kumpulan puisi Ayat-Ayat Api karya Sapardi Djoko Damono, serta informan. Teknik pengumpulan data yang digunakan yaitu wawancara dan analisis dokumen. Peneliti menggunakan triangulasi teori dan sumber data sebagai uji validitas data. Hasil penelitian ini adalah (1) terdapat 123 jenis gaya bahasa yang meliputi 34 gaya bahasa personifikasi, 32 gaya bahasa aliterasi, 21 gaya bahasa metafora, dan 14 gaya bahasa hiperbola; (2) terdapat 26 bentuk nilai moral yang berupa 11 aspek nilai berkata jujur, 7 aspek berbuat benar, 7 aspek berani, dan 1 aspek berlaku adil; (3) hasil temuan kumpulan puisi Ayat-Ayat Api karya Sapardi Djoko Damono ini relevan dan dapat digunakan sebagai bahan ajar sastra di SMA khususnya kelas $\mathrm{X}$ pada KD 3.17 tentang menganalisis unsur pembangun puisi.
\end{abstract}

Kata Kunci: puisi, gaya bahasa, stilistika, nilai moral, bahan ajar Bahasa Indonesia.

\section{LANGUAGE STYLES AND MORAL VALUES IN THE POETRY COLLECTION OF “AYAT-AYAT API” BY SAPARDI DJOKO DAMONO AS A LITERATURE TEACHING MATERIAL IN SENIOR HIGH SCHOOL}

\begin{abstract}
This study aims to describe (1) the type of language style; (2) types of moral values; and (3) the relevance of the findings of the poetry collection "Ayat-Ayat Api" by Sapardi Djoko Damono as a literature teaching materials in senior high schools. This type of research is a qualitative study using a stylistic approach. Sources of data for this research are documents on the types of language style and moral values in a collection of poetry "Ayat-Ayat Api" by Sapardi Djoko Damono, as well as informants. The data collection techniques used were interviews and document analysis. Researchers used theory triangulation and data sources as a test of data validity. The research results are as follows (1) there are 123 types of language styles including 34 personification styles, 32 alliteration styles, 21 metaphorical styles, and 14 hyperbole styles; (2) there are 26 forms of moral values that includes 11 aspects of the value of being honest, 7 aspects of doing right, 7 aspects of being brave, and 1 aspect of being fair; (3) the findings of the poetry collection "Ayat-Ayat Api" by Sapardi Djoko Damono are relevant and can be used as literary teaching materials in senior high school, especially class 10 at basic competency 3.17 on analyzing the building blocks of poetry.
\end{abstract}

Keywords: poetry, style of language, stylistics, moral values, Indonesian teaching materials.

BASASTRA Jurnal Bahasa, Sastra,dan Pengajarannya

Volume 9 Nomor 1, April 2021, P-ISSN 2302-6405, E-ISSN 2714-9765 


\section{PENDAHULUAN}

Suatu proses kegiatan belajar mengajar selalu berkaitan dengan penggunaan bahan ajar yang baik ditinjau dari segi kelayakannya. Bahan ajar dapat diartikan sebagai segala bentuk bahan yang dirancang dengan sistematis sehingga memungkinkan peserta didik mampu belajar secara mandiri dan dapat disusun sesuai kurikulum yang berlaku saat itu. Adanya bahan ajar ini memudahkan seorang guru dalam memberikan materi kepada peserta didiknya. Bahan ajar yang baik adalah bahan ajar yang terdiri dari berbagai sumber. Dalam pemilihan bahan ajar yang baik perlu memperhatikan beberapa aspek. Patokan dalam memilih bahan ajar, yaitu ketersediaan sumber; dana, tenaga, dan fasilitas; keluwesan, kepraktisan, dan daya tahan bahan ajar; serta efektivitas bahan ajar untuk waktu yang panjang (Komalasari, 2010: 126).

Bahan ajar yang baik tidak hanya dilihat dari isi kelayakan dari bahan tersebut, bahan ajar yang baik juga harus mengandung nilai moral yang baik untuk dipelajari. Nilai moral adalah segala sesuatu yang dianggap baik yang berkembang menjadi kebiasaan dalam bertingkah laku (baik buruk). Nilai moral ini penting untuk dipelajari, karena dengan mempelajari bisa untuk menerapkan dalam kehidupan sehari-hari. Selain nilai moral yang harus ada, bahan ajar yang baik harus mudah dipahami dari segi kebahasaannya. Bahasa yang digunakan dalam bahan ajar tersebut mudah dipahami dan dimengerti oleh semua kalangan. Semakin mudah, luwes, santun, dan praktis bahasa yang digunakan akan semakin mudah untuk dipahami dan dimengerti isi dari bahan ajar yang telah dipelajari tersebut.
Sejalan dengan apa yang telah terjadi di lapangan masih banyak dijumpai pengajar atau guru ini menggunakan bahan ajar dari buku siswa saja. Padahal jenis-jenis dari bahan ajar itu banyak dari berbagai sumber. Jenis-jenis bahan ajar bisa berupa bahan ajar cetak, bahan ajar dengar (audio), bahan ajar pandang, bahan ajar interaktif, bahan ajar yang tidak diproyeksikan, bahan ajar yang diproyeksikan, dan bahan ajar komputer. Tidak hanya masalah penggunaan bahan ajar yang kurang sumber, isi dari buku siswa ini juga terlalu sedikit mengandung nilai moral. Nilai moral yang ada dalam bahan ajar tersebut tidak banyak. Hasil survei penelitian di lapangan ini berdasarkan dari wawancara dengan guru dan siswa di sekolah SMA Gondangrejo. Hasil penelitian terdahulu yang dilakukan oleh peneliti-peneliti juga menemukan bahwa guru-guru hanya menggunakan buku siswa sebagai bahan ajar di sekolah itu.

Adapun pembelajaran sastra dalam pengajaran bahasa Indonesia juga masih ditemukan beberapa masalah. Keberadaan karya sastra masih sering disepelekan dan hanya dianggap sebagai pelengkap mata pelajaran bahasa. Padahal banyak ditemui dalam kehidupan sehari-hari manfaat yang diperoleh baik dari pembelajaran sastra terutama puisi. Pemilihan puisi yang digunakan dalam pembelajaran juga tidak sembarangan. Puisi tersebut harus mempunyai kriteria yang baik dan menarik. Bahasa yang digunakan indah dan mudah dipahami, terdapat nilai-nilai edukasi, dan selalu memberikan pengaruh yang positif bagi pembacanya. Kumpulan puisi Ayat-Ayat Api karya Sapardi Djoko Damono ini sangat cocok untuk 
dijadikan bahan ajar pembelajaran Bahasa Indonesia.

Kumpulan puisi Ayat-Ayat Api karya Damono (2017: 1-88) menceritakan kisah khusus membedah komentar sosial, seperti tragedi Mei 1998 yang terjadi di Jakarta dan di sejumlah kota lain menjelang 'Sang Jenderal' lengser keprabon. Kata ayat yang selalu akrab dalam kitab/suci agama Islam dan Kristen itu bukan lagi sekadar berarti "kalimat". Ayat yang sudah menjadi tanda. Ayat-ayat api menjadi tanda-tanda kehidupan (Soemanto, 2006). Api adalah lambang kehidupan, itu sebabnya rakyat Indonesia luluh lantak dalam kobarannya (Damono, 2017: 80). Buku antalogi ini terdiri dari tiga bab yaitu Ayat-Ayat Nol, Ayat-Ayat Arlogi, dan Ayat-Ayat Api. Damono mendesain peristiwa Tragedi Mei 1998 ini sedemikian rupa menjadi bait-bait puisi dan terkumpul menjadi satu kumpulan puisi indah berjudul Ayat-Ayat Api (Damono, 2017: 1-88). Pemilihan kata yang unik, gaya bahasa yang indah dan menakjubkan membuat peneliti tertarik untuk meneliti kumpulan puisi AyatAyat Api dengan kajian stilistika. Puisi tidak hanya berfungsi sebagai sarana hiburan tetapi juga berisi nilai-nilai kehidupan yang digambarkan melalui kata-kata di dalamnya, salah satunya adalah nilai moral yang positif (Yulianti, 2013: 1). Nilai-nilai kehidupan tersebut biasanya kurang familiar di kalangan remaja karena pada umumnya puisi yang dijadikan bahan ajar di sekolah sulit dipahami dengan latar kehidupan siswa yang suda sangat berbeda-beda (Harjono, 2012: 23). Dengan demikian, penelitian ini dilakukan untuk memudahkan siswa agar dapat memahami makna dan nilai kehidupan dalam puisi.
Salah satu kumpulan-puisi yang cocok dengan penggunaan gaya bahasa dalam penulisannya adalah kumpulan puisi Ayat-Ayat Api karya Sapardi Djoko Damono. Majas/gaya bahasa yang dipergunakan oleh penyair dengan tujuan untuk memperindah kata sehingga menarik untuk dibaca. Dengan demikian, bahasa yang digunakan seolah-olah hidup, berjiwa, dan bermakna sehingga dapat menggetarkan hati pembaca atau pendengar. Seperti yang diketahui bahwa gaya bahasa itu mencakup semua jenis ungkapan yang bermakna lain dengan makna yang harfiah bisa berupa kata, frasa ataupun satuan sintaksis yang lebih luas. Gaya yaitu bentuk retorik dari penggunaan katakata dalam berbicara maupun menulis untuk memengaruhi dan meyakinkan pembaca atau pendengar mengenai isi dari puisi tersebut (Tarigan, 2009: 12). Sapardi Djoko Damono ialah seorang guru besar di Fakultas Sastra Universitas Indonesia (UI) yang sangat ahli dan sudah tidak diragukan lagi kemampuannya. Selain buku kumpulan puisi Ayat-Ayat Api, beliau juga menulis buku-buku sastra antara lain: Sosiologi Sastra: Sebuah Pengantar Ringkas (1978), Sastra Indonesia Modern: Beberapa Catatan (1983), Novel Sastra Indonesia Sebelum Perang (1979), Sihir Rendra, Permainan Makna (1999), Hujan Bulan Juni (1991), dan lain sebagainya.

Kumpulan Puisi Ayat-Ayat Api memiliki tema yang sangat berbedabeda, misalnya sosial masyarakat, renungan-kehidupan, dan cerita pribadi pengarang. Keanekaragaman tema yang diangkat dalam kumpulan puisi Ayat-Ayat Api menarik untuk dikaji dengan menggunakan pendekatan stilistika. Kajian stilistika berupaya 
untuk menunjukkan bagaimana unsurunsur suatu teks berkombinasi membentuk suatu pesan dan memberikan gambaran secara lengkap bagaimana nilai keindahan yang ada dalam sebuah karya sastra itu sendiri (Subadiyono, 2008: 134). Kajian atau ruang lingkup yang ditelaah stilistika menurut Sudjiman (1993: 42) merupakan style sebagai gaya bahasa yang mencakup diksi, struktur kalimat, majas, pola rima dan mantra yang digunakan pengarang dalam karyanya. Namun, secara umum peneliti hanya memfokuskan pada gaya bahasa.

Penelitian terkait hal tersebut sudah pernah dilakukan dan diteliti oleh peneliti sebelumnya yaitu Rohayati (2014) dengan judul penelitian Gaya Bunyi dan Majas dalam Kumpulan Puisi Ayat-Ayat Api Karya Sapardi Djoko Damono: Kajian Stilistika dan Implementasinya pada Pembelajaran di SMP. Penelitian ini membedakan sebelumnya dengan penelitian sekarang ini adalah dari segi pembahasan dan teori yang digunakan. Penelitian sekarang yang dilakukan peneliti adalah dengan lebih menekankan dan memfokuskan pembahasan tentang gaya bahasa saja. Hal yang dikaji lebih detail dan lebih jelas. Peneliti sekarang tidak hanya mengkaji gaya bahasanya saja tetapi juga nilai moral yang ada pada kumpulan puisi Ayat-Ayat Api ini dengan merelevansikan sebagai bahan ajar Bahasa Indonesia di SMA. Hasil temuan tentang analisis stilistika yang membahas gaya bahasa dan nilai moral yang terdapat dalam kumpulan puisi Ayat-Ayat Api karya Sapardi Djoko Damono dapat juga direlevansikan sebagai bahan ajar Bahasa Indonesia di sekolah menengah atas. Di kelas X SMA Kurikulum 2013, terdapat kompetensi dasar pada KD 3.17 yaitu menganalisis unsur pembangun puisi dan KD 4.17 menulis puisi dengan memperhatikan unsur pembangunnya. Guru dapat menggunakan penggalan salah satu puisi dari kumpulan puisi Ayat-Ayat Api sebagai bahan ajar dalam menganalisis unsur pembangun puisi. Selain itu, siswa dapat mengambil contoh nilai moral yang terdapat dalam kumpulan puisi AyatAyat Api untuk diaplikasikan pada kehidupan sehari-hari. Berdasarkan hal-hal tersebut, peneliti tertarik untuk melakukan penelitian terhadap kumpulan puisi Ayat-Ayat Api karya Damono. Penelitian ini berjudul Gaya Bahasa dan Nilai Moral dalam Kumpulan Puisi Ayat-Ayat Api Karya Sapardi Djoko Damono sebagai Bahan Ajar Bahasa Indonesia di SMA.

\section{METODE}

Bentuk penelitian ini adalah deskriptif kualitatif dengan pendekatan stilistika. Penelitian deskriptif bertujuan untuk mendeskripsikan dan menjelaskan jenis-jenis gaya bahasa, jenis-jenis nilai moral, dan relevansi sebagai bahan ajar Bahasa Indonesia. Data dalam penelitian ini adalah hasil analisis dokumen kumpulan puisi AyatAyat Api karya Sapardi Djoko Damono yang diterbitkan oleh PT Gramedia Pustaka Utama pada tahun 2017 dengan jumlah halaman 88 halaman. Sementara sumber data berupa dokumen jenis gaya bahasa dan nilai moral kumpulan puisi Ayat-Ayat Api serta informan (guru Bahasa Indonesia SMA dan ahli sastra).

Teknik pengumpulan data yang digunakan oleh peneliti yaitu wawancara dan analisis dokumen. Analisis data dilakukan dengan cara membaca berulang-ulang dan 
diimbangi membaca referensi terkait kajian stilistika. Proses pemerolehan data selanjutnya yaitu mengumpulkan semua data yang ada di dalam kumpulan puisi sebagai bukti atau keterangan terkait masalah yang dikaji, kemudian data dianalisis. Proses akhir dari pengumpulan data ini yakni melakukan wawancara dengan guru untuk mengetahui relevansi dengan bahan ajar.

Teknik analisis data yang digunakan oleh peneliti adalah model analisis interaktif yang dikemukakan oleh Milles dan Huberman meliputi reduksi data, sajian data, dan verifikasi. Sementara uji validitas data menggunakan triangulasi teori dan sumber data. Triangulasi sumber data digunakan untuk mengumpulkan data melalui hasil wawancara dengan ahli sastra dan guru, sedangkan triangulasi teori diperoleh dari teori-teori yang digunakan oleh peneliti dalam penelitian ini.

\section{HASIL DAN PEMBAHASAN}

\section{Proses Kreatif Pengarang}

Sastrawan Sapardi Djoko Damono lahir di kota Surakarta, 20 Maret 1940. Ia merupakan pujangga Indonesia yang terkenal lewat karyakarya sastranya berupa puisi. Masa kecil Damono dihabiskan di Kota Surakarta. Riwayat pendidikannya yakni alumni SMP Negeri 2 Surakarta tahun 1955 dan SMA Negeri 2 Surakarta tahun 1958. Kegemarannya menulis berkembang saat ia sedang menjalani kuliah bidang Bahasa Inggris di Universitas Gadjah Mada, hingga saat ini karya-karyanya masih melegenda.

Adapun karya-karya Damono yang diterbitkan Gramedia Pustaka
Utama berupa Hujan Bulan Juni, Melipat Jarak, Babad Batu, Bilang Begini Maksudnya Begitu, dan tiga buku fiksi (Trilogi Soekram, Hujan Bulan Juni, dan Pingkan Melipat Jarak). Ada enam puisi karyanya yang terbit serentak tahun 2017 yakni, DukaMu Abadi, Ayat-ayat Api, Ada Berita Apa hari ini, Den Sastro, Kolam, Sutradara itu Menghapus Dialog Kita, dan Namaku Sita. Dari beberapa karya sastra yang sudah dihasilkan oleh Damono, ada juga karya nonfiksi dalam bentuk musikalisasi puisi. Beberapa karyanya juga pernah mendapat penghargaan dan menjadi karya populer. Kumpulan puisi AyatAyat Api merupakan karya Damono yang terbit pada tahun 2017 , terdiri 88 halaman.

\section{Kedudukan Pengarang dalam Sastra Indonesia}

Kedudukan seorang Sapardi Djoko Damono dalam dunia sastra Indonesia tidak perlu diragukan lagi. Beberapa hasil karyanya sangat populer di masyarakat bahkan kalangan sastrawan, sehingga ia memiliki banyak penggemar dan menjadi panutan sastrawan-sastrawan lain, banyak karya-karyanya yang dipakai untuk bahan penelitian (Ni'mah, 2019). Ia pun dapat dikenal masyarakat luar karena sering menerima penghargaan. Adapun penghargaan yang pernah ia raih yaitu, Cultural Award pada tahun 1978 dari Australia, Anugerah Puisi Putra tahun 1983 dari Malaysia, dan anugerah SEA Write Award tahun 1985 dari Thailand.

Selain prestasinya dalam ranah internasional, peran Damono dalam dunia sastra Indonesia dibuktikan dengan diprakarsainya Himpunan Sarjana Kesusastraan Indonesia 
(HISKI). Sebelumnya, ia juga pernah menjadi Dekan dan Guru Besar di Fakultas Ilmu Budaya UI serta redaktur majalah Horison, Basis, dan Kalam.

\section{Jenis Gaya Bahasa (Majas) dalam Kumpulan Puisi Ayat-Ayat Api Karya Sapardi Djoko Damono}

Teori tentang jenis-jenis gaya bahasa yang digunakan dalam penelitian ini yaitu menurut pendapat Nurdin, dkk. (2004: 21-30). Fokus dari penelitian ini akan menggunakan teori jenis majas menurut pendapat Nurdin karena dengan menggunakan teori yang diungkapkan sangat cocok dan terdapat banyak variasi yang sesuai dengan isi kumpulan puisi Ayat-Ayat Api karya Sapardi Djoko Damono tersebut.

Kumpulan puisi Ayat-Ayat Api karya Sapardi Djoko Damono dianalisis berdasarkan penggunaan majas yang paling banyak berdasarkan lima kelompok jenis gaya bahasa. Adapun hasil temuan jenis gaya bahasa dalam kumpulan puisi Ayat-Ayat Api dapat dilihat pada tabel di bawah ini.

Tabel 1. Jenis Gaya Bahasa dalam Kumpulan Puisi Ayat-Ayat Api

\begin{tabular}{llcc}
\hline No. & $\begin{array}{l}\text { Jenis Gaya } \\
\text { Bahasa }\end{array}$ & Frekuensi & $\begin{array}{c}\text { Persentase } \\
(\%)\end{array}$ \\
\hline 1. & Hiperbola & 14 & 11.3 \\
2. & Simile & 4 & 3.2 \\
3. & Metafora & 21 & 17.0 \\
4. & Personifikasi & 34 & 27.6 \\
5. & Metonimia & 2 & 1.6 \\
6. & Sinekdoke & - & - \\
7. & Alusio & - & - \\
8. & Eponim & - & - \\
9 & Eufemisme & - & - \\
10. & Epitet & 1 & 0.8 \\
11. & Litotes & - & - \\
12. & Paradoks & 1 & 0.8 \\
13. & Oksimoron & - & - \\
14. & Antitesis & 1 & 0.8 \\
15. & Histeron & - & - \\
16. & Prosteron & 1 & 0.8 \\
17. & Repetisi & - & - \\
18. & Paralelisme & 32 & 26.0 \\
\hline
\end{tabular}

\begin{tabular}{llcc}
\hline 19. & Aliterasi & 3 & 2.4 \\
20. & Anafora & 3 & 2.4 \\
21. & Epizeuksis & 1 & 0.8 \\
22. & Epanalepsis & 1 & 0.8 \\
24. & Mesodiplosis & - & - \\
25. & Anadiplosis & 2 & 1.6 \\
26. & Sinisme & - & - \\
27. & Innuendo & - & - \\
28. & Antifrasis & 1 & 0.8 \\
29. & Sarkasme & 1 & 0.8 \\
& Satire & & \\
& & & \\
& \multirow{2}{*}{ Jumlah : 123} & & \\
\hline
\end{tabular}

Berdasarkan data pada Tabel 1, dapat disimpulkan bahwa penggunaan jenis gaya bahasa yang ditemukan yaitu personifikasi, aliterasi, metafora, dan hiperbola, sehingga peneliti memfokuskan penelitian ini pada gaya bahasa tersebut.

\section{Bentuk Nilai Moral yang Terkandung dalam Kumpulan Puisi Ayat-Ayat Api Karya Sapardi Djoko Damono}

Teori mengenai aspek-aspek perilaku moral yang penulis gunakan dalam penelitian ini yaitu menurut pendapat Daradjat (dalam Munawaroh, 2017: 28) yang menyebutkan empat kriteria nilai moral meliputi: aspek perilaku moral berkata jujur, berbuat benar, berlaku adil, dan berani. Adapun bentuk nilai moral yang tersirat pada kumpulan puisi Ayat-Ayat Api dapat dicermati pada tabel tersebut.

Tabel 2. Bentuk Nilai Moral dalam Kumpulan Puisi Ayat-Ayat Api

\begin{tabular}{llcc}
\hline No. & $\begin{array}{c}\text { Jenis } \\
\text { Nilai } \\
\text { Moral }\end{array}$ & Frekuensi & $\begin{array}{c}\text { Persentase } \\
(\%)\end{array}$ \\
\hline 1. & Berkata & 11 & 42.3 \\
2. & Jujur & 7 & 26.9 \\
3. & Berbuat & 1 & 3.8 \\
4. & Benar & 7 & 26.9 \\
& Berlaku & & \\
& Adil & & \\
& Berani & & \\
\hline
\end{tabular}




\begin{tabular}{l}
\hline Jumlah : 26 \\
$100 \%$ \\
\hline
\end{tabular}

Berdasarkan penjabaran data hasil temuan pada Tabel 2, diperoleh data bahwa terdapat 26 nilai moral yang terbagi dalam empat kriteria. Terdapat sebanyak 11 kali nilai moral berkata jujur dengan persentase sebanyak $42.3 \%$, sedangkan nilai moral lainnya meliputi: berbuat benar sebanyak 7 kali atau $26.9 \%$, berlaku adil sebanyak 1 kali atau $3.8 \%$, dan berani sebanyak 7 kali atau $26.9 \%$.

Relevansi Hasil Temuan dalam Kumpulan Puisi Ayat-Ayat Api Karya Sapardi Djoko Damono sebagai Bahan Ajar Bahasa Indonesia di SMA

Pada kurikulum 2013 mata pelajaran Bahasa Indonesia kelas $\mathrm{X}$ terdapat $\mathrm{KD}$ tentang menganalisis unsur pembangun puisi (KD 3.17). Selain itu terdapat kegiatan keterampilan dengan KD menulis puisi dengan memperhatikan unsur pembangunnya yaitu KD 4.17.

Hasil temuan berupa penggunaan diksi, majas, citraan, dan nilai moral pada kumpulan puisi Ayat-Ayat Api karya Sapardi Djoko Damono tersebut dapat diterapkan dan digunakan sebagai bahan ajar dalam menganalisis unsur pembangun puisi jika hasil temuan tersebut relevan. Kelayakan sebuah karya sastra untuk dijadikan bahan ajar tentunya disesuaikan dengan banyak kriteria.

Berdasarkan panduan pengembangan bahan ajar diutarakan menurut Depdiknas (2008: 28) ada empat kriteria dalam evaluasi kelayakan bahan ajar, meliputi kelayakan isi, kebahasaan, penyajian, dan kegrafikan, sementara Siregar dan
Hartini (2011: 130) mengatakan, kriteria dalam menentukan kelayakan bahan ajar harus memperhatikan tujuan yang dicapai, mudah didapat, serta fleksibel. Kelayakan buku kumpulan puisi Ayat-Ayat Api ini sudah melalui penilaian dengan panduan Permendikbud 2008, hasil menyatakan buku tersebut layak untuk dijadikan bahan ajar, untuk skor kelayakan dapat dilihat dalam lampiran.

\section{Gaya Bahasa (Majas) dalam Kumpulan Puisi Ayat-Ayat Api Karya Sapardi Djoko Damono}

Berdasarkan hasil temuan penelitian terhadap kumpulan puisi Ayat-Ayat Api karya Sapardi Djoko Damono didapatkan sebanyak 123 gaya bahasa (majas). Frekuensi penggunaan masing-masing majas yaitu majas hiperbola sebanyak 14 kali, simile 4 kali, metafora 21 kali, personifikasi 34 kali, metonima 2 kali, sinekdoke, alusio, eponim, dan eufemisme 0 kali, epitet 1 kali, paradoks 1 kali, litotes dan oksimoron 0 kali, antitesis 1 kali, hysteron prosteron 0 kali, repetisi 1 kali, paralelisme 0 kali, aliterasi $32 \mathrm{kali}$, anafora 3 kali, epizeuksis 3 kali, epanalepsis 1 kali, mesodiplosis 1 kali, anadiplosis 0 kali, sinisme 2 kali, innuendo dan antifraksis 0 kali, sarkasme dan satire 2 kali. Peneliti hanya memilih 4 gaya bahasa/majas yang paling dominan digunakan yaitu personifikasi, aliterasi, metafora, dan hiperbola. Adapun analisis gaya bahasa (majas) personifikasi, aliterasi, metafora, dan hiperbola yang digunakan dalam kumpulan puisi AyatAyat Api sebagai berikut. 


\section{Personifikasi}

Data yang telah didapatkan, majas personifikasi yang digunakan dalam kumpulan puisi Ayat-Ayat Api sebanyak 34 buah. Data tersebut dianalisis secara keseluruhan dan diambil beberapa contoh saja. Penyebaran penggunaan majas personifikasi didominasi pada bagian awal hingga akhir selalu ada majas tersebut yaitu dimulai dari halaman 379, bagian dari bab Ayat-Ayat Nol, Ayat-Ayat Arloji, dan Ayat-Ayat Api, bagian yang paling mendominan adalah bagian Ayat-Ayat Nol dan AyatAyat Arloji, ketika cerita/konflik menceritakan tentang Marsinah yang mati terbunuh dengan segala misteri yang ada dibalik kematiannya. Penggunaan majas dalam penggambaran cerita bagian ini cocok untuk memperkuat perumpamaan setiap keadaan. Berikut adalah contoh penggunaan majas personifikasi dalam kumpulan puisi Ayat-Ayat Api.

1) kau seolah mengerti: tak ada lubang angin di ruang terkunci ini (Damono, 2017: 3)

2) percik-percik cahaya. Lalu kembali hijau namamu, daun yang menjelma kupu-kupu (Damono, 2017: 5)

3) aku tengah menantimu, mengejang bunga randu alas (Damono, 2017: 7)

Contoh di atas disebut sebagai majas personifikasi karena penyair mencoba menyamakan suatu objek benda-benda mati dengan manusia. Contoh 1 dijelaskan kau seolah mengerti: tak ada lubang angin di ruang terkunci ini dapat diartikan dengan semesta yang luas dengan penuh kerahasiaan. Kata lubang angin termasuk majas personifikasi karena menyamakan lubang angin dengan yang dimiliki manusia, seperti contohnya lubang hidung yang terdapat di bagian tubuh manusia.

Contoh penggunaan majas personifikasi lainnya dapat dilihat pada contoh 2. Pada contoh 2, penyair menyamakan daun dengan manusia yang dapat menjelma menjadi kupukupu. Keadaan tersebut dapat dianalogikan bahwa yang dapat menjelma atau berubah itu biasanya manusia. Daun benda mati tidak dapat berubah.

Selain itu, contoh 3 menunjukkan adanya kata mengejang bunga randu alas. Sedangkan, arti kata mengejang itu sendiri adalah mulai menjadi kejang, karena panas badannya tinggi, tangan dan kakinya. Merasakan hal seperti ini seharusnya dirasakan oleh manusia, pohon atau bunga tidak dapat merasakan itu.

Berdasarkan contoh di atas, gaya bahasa personifikasi digunakan oleh penyair untuk menyamakan suatu hal benda mati dengan manusia yang mengapit kata pembanding. Hasil teori penelitian serupa dilakukan oleh (Mubarok, 2015), menjelaskan bahwa gaya bahasa personifikasi adalah sebagai gaya bahasa yang memberi efek kiasan terhadap suatu kalimat yang terdapat kata tersebut bisa menggambarkan benda-benda mati atau yang tidak bernyawa selah-olah memiliki sifat seperti manusia.

\section{Aliterasi}

Data yang didapatkan, majas aliterasi yang digunakan dalam kumpulan puisi Ayat-Ayat Api sebanyak 32 buah. Penyebaran penggunaan majas aliterasi didominasi pada bagian awal dan tengah cerita dengan banyaknya menggunakan kata yang berulang yang disampaikan 
penyair. Data-data tersebut dianalisis keseluruhan. Dalam pembahasan kali ini peneliti hanya mengambil beberapa contoh majas aliterasi yang dicantumkan. Berikut adalah contoh penggunaan majas aliterasi dalam kumpulan puisi Ayat-Ayat Api.

1) pasti dikenalnya kembali aku suara langkahku, nafasku (Damono, 2017: 10)

2) di hari baik bulan baik, Marsinah dijemput di rumah tumpangan (Damono, 2017: 23)

3) Marsinah diseret dan dicampakan sempurna, sendiri (Damono, 2017: 24)

Dari contoh di atas bisa dikategorikan sebagai gaya bahasa/majas aliterasi karena terdapat perulangan kata atau frasa konsonan yang sama. Hal itu sesuai dengan pengertian aliterasi yaitu memanfaatkan kata-kata yang permulaan bunyinya sama (Nurdin, dkk., 2004: 28).

Contoh 1 terdapat pengulangan konsonan dan permulaan bunyinya sama, yaitu kata langkahku nafasku. Pengulangan kata langkahku nafasku pada contoh 1 dimaksudkan untuk menyebutkan bahwa di setiap langkahnya adalah napas yang berarti kehidupan. Segala apa pun yang akan dilakukan dan dijalani harus dengan penuh hati-hati untuk kehidupan yang baik dan nantinya setiap langkah itu akan sangat berarti dan berpengaruh kepada kehidupannya.

Kemudian pada contoh 2 menggunakan kata perulangan yang konsonannya sama. Penyair menggunakan perulangan kata baik bulan baik tersebut dengan tujuan untuk memperkuat hari dan bulan itu baik. Penyair ingin menjelaskan di hari baik bulan baik itu Marsinah dijemput di rumah tumpangan untuk menghadiri sebuah perhelatan atau acara.

Selain itu contoh penggunaan gaya bahasa/majas aliterasi dapat dilihat pada contoh 3. Pada contoh 3 digunakan kata perulangan yang konsonannya sama yaitu kata sempurna, sendiri. Perulangan kata tersebut digunakan untuk menjelaskan keadaan Marsinah yang diseret dan dicampakkan seorang diri sempurna dengan penderitaannya.

Teori serupa tentang gaya bahasa aliterasi juga dikemukakan oleh (Widayanti, 2019), semacam gaya bahasa yang berwujud dengan perulangan konsonan yang sama pada kumpulan puisi.

Penulis menyimpulkan jika Damono (2017), menggunakan majas aliterasi yang juga lebih banyak dengan tujuan menciptakan gagasan dan emosi dalam kumpulan puisi Ayat-Ayat Api ini menjadi lebih nyata. Hal tersebut didukung pendapat (Keraf, 2008: 127) yang menyatakan bahwa gaya bahasa ini yang kerap berwujud perulangan konsonan yang sama.

\section{Metafora}

Data yang diperoleh, majas metafora yang digunakan dalam kumpulan puisi Ayat-Ayat Api sebanyak 21 buah. Penyebaran penggunaan majas metafora ini didominasi pada bagian tengah cerita dengan banyaknya menggunakan kata perbandingan yang disampaikan penyair menggunakan kata kiasan yang bukan makna sebenarnya. Data-data tersebut dianalisis keseluruhan. Dalam pembahasan ini peneliti hanya mengambil beberapa contoh majas metafora yang dibahas. Berikut ini adalah contoh penggunaan majas 
metafora dalam kumpulan puisi AyatAyat Api.

1) kau cari catatan kaki itu, sia-sia (Damono, 2017: 3)

2) pemburu mencari jejak pancaindra (Damono, 2017: 15)

3) margasatwa membusuk di tepi sungai kering (Damono, 2017: 15)

Dari contoh di atas bisa dikategorikan sebagai gaya bahasa/majas metafora karena terdapat kata atau frasa yang menggunakan kiasan untuk membandingkan objek. Hal itu sesuai dengan pengertian metafora yaitu penggunaan kata-kata atau frasa yang menggunakan kiasan yang sama, tetapi nyatanya beda (Nurdin, dkk., 2004: 23).

Contoh 1 terdapat gaya bahasa metafora yang menggunakan kiasan. Frasa tersebut adalah catatan kaki yang memiliki arti sebuah keterangan khusus yang ditulis di karangan ilmiah. Catatan kaki menurut puisi tersebut bermakna seseorang yang mencari jejak itu akan sia-sia.

Gaya bahasa metafora juga dapat ditemukan di contoh 2. Pada contoh 2 terdapat frasa kiasan yaitu jejak pancaindra. Arti dari frasa tersebut adalah tanda atau bekas langkah dan tingkah laku dari semua perasa telah ada dan dirasakan.

Selanjutnya, dapat ditemukan gaya bahasa metafora dari contoh 3 . Contoh 3 di sini menggunakan kata margasatwa dalam puisi yang disampaikan kepada pembaca. Margasatwa itu sendiri memiliki arti kata habitat dan kehidupan yang biasanya untuk tempat tinggal hewan.

Teori penelitian yang relevan dan serupa juga diungkapkan oleh (Luanmas, 2015), metafora adalah gaya bahasa perbandingan dan persamaan yang membandingkan sesuatu dengan sesuatu hal yang lain, berarti menemukan ciri-ciri yang menunjukkan kesamaan antara dua hal. Teori serupa juga dari (Rey, 2019), yaitu gaya bahasa yang mirip dan sama yang dapat ditanggapi oleh pancaindra.

\section{Hiperbola}

Data yang telah didapatkan, majas hiperbola yang digunakan dalam kumpulan puisi Ayat-Ayat Api sebanyak 14 buah. Data tersebut telah dianalisis secara keseluruhan dan diambil beberapa contoh saja. Penyebaran untuk penggunaan majas hiperbola ini didominasi pada bagian tengah selalu ada yang menggunakan majas tersebut. Penggunaan majas dalam penggambaran cerita sangat cocok untuk memperkuat dan menegaskan setiap keadaan. Berikut adalah contoh penggunaan majas hiperbola dalam kumpulan puisi AyatAyat Api.

1) menyayat garis-garis hitam (Damono, 2017: 8)

2) anak perempuannya suka menatapnya aneh jika ia menirukan lagu iklan supermi,

kepalanya bergoyang-goyang dan matanya berbinar-binar (Damono, 2017: 30)

3) setelah menempuh hutan, menyusur sungai, mendaki gunung, dan meluncur di padang salju sampailah ia ke sebuah ladang pasir (Damono, 2017: 34)

Contoh di atas bisa dikategorikan sebagai gaya bahasa/majas hiperbola karena terdapat kata atau frasa yang menggunakan bahasa yang berlebihlebihan untuk menegaskan dan menekankan suatu objek. Hal itu sesuai dengan pengertian hiperbola yaitu 
penggunaan kata-kata atau frasa yang berlebih-lebihan dengan tujuan untuk menekankan dan menegaskan (Nurdin, dkk., 2004: 22).

Contoh 1 terdapat gaya bahasa hiperbola yang menggunakan kata berlebihan. Frasa tersebut adalah menyayat garis-garis hitam. Kata menyayat ini dianggap berlebihan karena memiliki arti mengiris-iris. Dan garis-garis hitam ini bisa diartikan penyatuan garis-garis yang bertinta hitam yang tak pernah terputus.

Pemakaian gaya bahasa hiperbola ini juga terdapat pada contoh 2. Pada contoh 2 ini terdapat kata yang menggunakan bahasa yang berlebihan yaitu kepalanya bergoyang-goyang dan matanya berbinar-binar. Kalimat pada larik puisi tersebut telah melebihlebihkan tindakan seseorang, dengan penyebutan matanya sangat terpanah ketika melihat sesuatu dan kepalanya tak henti-hentinya bergerak.

Gaya bahasa hiperbola juga ada pada contoh 3, karena pada contoh tersebut juga terdapat frasa yang menggunakan kata secara berlebihan. Kalimat tersebut yaitu setelah menempuh hutan, menyusur sungai, mendaki gunung, dan meluncur di padang salju. Pada kalimat tersebut penyair mendramatisasi keadaan yang seolah-olah membutuhkan perjuangan yang berat untuk mencapai tempat yang hendak dituju.

Teori serupa juga mengatakan bahwa gaya bahasa hiperbola adalah gaya bahasa yang mengandung pernyataan yang melebih-lebihkan dengan tujuan memberikan kesan penekanan pada pernyataan tersebut sehingga dapat memperhebat pengaruhnya dan kesannya pada lariklarik puisi (Sitompul, 2014). Hal ini juga memengaruhi sebuah puisi akan menjadi indah dan menarik untuk dibaca, karena memberikan kesan mendramatisasi isi pesan yang akan disampaikan kepada pembaca.

\section{Nilai Moral dalam Kumpulan Puisi Ayat-Ayat Api Karya Sapardi Djoko Damono}

\section{Nilai Moral Bekata Jujur}

Hasil penelitian, terdapat 11 aspek nilai moral berkata jujur yang ada dalam kumpulan puisi Ayat-Ayat Api. Dari kesebelas aspek nilai moral berkata jujur yang sudah ditemukan, penulis akan mengambil beberapa contoh untuk dianalisis lebih detail. Berikut adalah contoh nilai moral berkata jujur yang terdapat dalam kumpulan puisi Ayat-Ayat Api.

Marsinah, kita tahu, tak bersenjata,

Ia hanya suka merebus kata

Sampai mendidih,

Lalu meluap ke mana-mana (Damono, 2017: 22)

Pada contoh, penyair ingin memunculkan sifat yang berkata jujur melalui kata-kata Marsinah, kita tahu, tak bersenjata. Analisis perkataan seorang yang tahu akan kejadian yang dialami Marsinah yang tidak berdaya dengan tangan kosong dan tidak memiliki senjata untuk melawan pejabat-pejabat itu dengan berkata seperti itu menandakan bahwa ia berkata jujur melawan para petinggi.

Teori tentang nilai moral jujur adalah segala sesuatu yang mendasari rasa kepercayaan, dan kepercayaan itu akan melandasi sebuah hubungan (Wulandari, 2002). Teori serupa lainnya tentang berkata jujur adalah nilai dan norma yang baik dalam lingkungan kehidupan (Muhasim, 2017). Tujuan penyair memunculkan 
aspek nilai moral berkata jujur ini agar pembaca/pendengar dapat menerapkannya di kehidupan seharihari untuk selalu berkata dan memberikan ungkapan pendapat yang jujur sesuai dengan kejadian yang sebenarnya.

\section{Nilai Moral Berbuat Benar}

Hasil penelitian terdapat 7 aspek nilai moral berbuat benar yang ada dalam kumpulan puisi Ayat-Ayat Api. Penulis akan mengambil beberapa contoh aspek nilai moral berbuat benar untuk dikaji lebih dalam dari hasil keseluruhan data yang diperoleh. Berikut adalah contoh aspek nilai moral berbuat benar yang terdapat dalam kumpulan puisi Ayat-Ayat Api.

1) Aku anak laki-laki,

2) tidak boleh menangis, kata Ibu (Damono, 2017: 31)

Pada contoh 1 dijelaskan sikap seorang anak laki-laki yang selalu ingat dan menerapkan pesan yang telah disampaikan oleh Ibunya. Hal tersebut dibuktikan dengan kata Aku anak lakilaki, tidak boleh menangis, kata Ibu. Sikap tersebut sesuai dengan ajaran agama yang memerintah kita agar mematuhi dan selalu ingat dengan nasihat dan pesan orang tua tentang apa yang telah disampaikan kepada kita sebagai anak.

Teori yang membahas tentang penelitian nilai moral berbuat benar dilakukan oleh (Machmud, 2014), yaitu nilai berbuat benar dengan mengembangkan nilai norma yang berada di masyarakat sesuai aturan. Dari kelima contoh di atas, penyair ingin agar pembaca/pendengar berbuat benar sesuai peraturan yang berlaku meskipun terkadang mengesampingkan perasaan iba.
Temuan aspek nilai moral yang paling dominan yaitu berkata jujur. Pengarang ingin agar pembaca mencontoh atau menerapkan aspek berkata jujur dan benar ini dalam kehidupannya sehari-hari. Untuk selalu mengungkapkan dan memberikan pernyataan yang sesuai dengan kejadian yang sesungguhnya dan juga sesuai keaslian realitas yang ada.

Relevansi Hasil Temuan dalam Kumpulan Puisi Ayat-Ayat Api Karya Sapardi Djoko Damono sebagai Bahan Ajar Bahasa Indonesia di SMA

Peran bahan ajar dalam kegiatan pembelajaran sangat penting. Penggunaan bahan ajar yang berkualitas dapat memengaruhi penyampaian ilmu dari pendidik kepada peserta didik. Pengertian bahan ajar sendiri menurut Prastowo (2012: 16), segala bahan (baik infromasi, alat, maupun teks) yang disusun secara sistematis dan utuh dari kompetensi yang akan dikuasai siswa dan digunakan dalam proses pembelajaran dengan tujuan perencanaan serta penelaah implementasi pembelajaran.

Selain itu, tentang kelayakan materi/isi, hasil temuan dalam puisi Ayat-Ayat Api memiliki keunggulan dan kekurangan masing-masing, tetapi secara spesifik hasil temuan sudah sangat beragam dan tidak mengandung unsur SARA. Hal tersebut sesuai dengan pendapat dari narasumber 1 bahwa,

"Meskipun penggunaan kata pada karya ini sudah bagus, majas juga beragam, tetapi perlu adanya seleksi pada majas yang dirasa terlalu sulit bagi siswa SMA agar hasil temuan majas bahkan nilai moral tersebut relevan dijadikan sebagai bahan ajar." 
Kemudian dari segi penyajian, hasil temuan dalam puisi ini sudah baik, dilihat dari keunikan atau keberagaman unsur-unsur instrinsiknya berupa majas serta penyajian isi yang mengembangkan karakter. Hal tersebut diperkuat dengan pendapat dari narasumber 2 mengemukakan bahwa, majas dalam karya ini sangat baik karena mampu menghadirkan nuansa baru dari kombinasi suasana perjuangan Marsinah seorang buruh pabrik arloji biasa yang berani membela dan memperjuangkan hak. Sementara itu, nilai moral dalam karya ini alangkah baiknya diarahkan pada kritik sosial atas ketimpangan perempuan mengenai keberanian dan kejujuran untuk selalu bertindak bebuat sesuai dengan aturan dan memperjuangkan hak walau pejabat tinggi menghiraukan tindakan yang benar terus maju pantang mundur tanpa dibebani hal serupa, sehingga hal tersebut dapat dipertimbangan dalam kelayakan sebagai bahan ajar.

\section{Sementara}

kriteria kebahasaannya, hasil temuan puisi ini sudah memperhatikan segi etis, estetis, dan sesuai ejaan. Dari hasil wawancara di atas, peneliti mendapatkan data jika hasil temuan majas dan nilai moral dalam kumpulan puisi Ayat-Ayat Api dapat direlevansikan sebagai bahan ajar Bahasa Indonesia siswa SMA khususnya KD 3.17 tentang menganalisis unsur pembangun puisi jika nilai moral dalam karya tersebut diarahkan pada keberanian dan bertindak adil, bahkan jujur untuk selalu membela dan memperjuangkan hak yang benar. Selain itu perlu adanya seleksi hasil temuan majas yang sekiranya sulit bagi kalangan siswa SMA.
Sementara itu hasil temuan tersebut mudah didapat dan fleksibel karena buku karya Sapardi Djoko Damono ini tersedia pada toko-toko buku serta fleksibel mengikuti perkembangan kosa kata pada saat ini, sehingga peserta didik dapat lebih mudah memahaminya.

\section{SIMPULAN}

Berdasarkan rumusan masalah, tujuan penelitian, hasil temuan dan pembahasan terhadap kumpulan puisi Ayat-Ayat Api karya Sapardi Djoko Damono didapatkan simpulan sebagai berikut:

Kumpulan puisi Ayat-Ayat Api karya Sapardi Djoko Damono terdapat beberapa jenis gaya bahasa yang digunakan. Gaya bahasa ini dikelompokkan menjadi 5 yaitu gaya bahasa penegasan, perbandingan, pertentangan, sindiran, dan perulangan. Gaya Bahasa dalam kumpulan puisi Ayat-Ayat Api sudah dikembangkan dengan baik, secara tepat dan mudah untuk dipahami. Dalam kumpulan puisi Ayat-Ayat Api banyak ditemukan gaya bahasa, hasil gaya bahasa/majas diperoleh gaya bahasa personifikasi, hiperbola, aliterasi dan metafora. Dari hasil temuan tersebut, peneliti menyimpulkan majas yang paling dominan digunakan yaitu majas aliterasi. Tujuan pengarang menggunakan majas aliterasi dan personifikasi lebih banyak daripada majas lainnya untuk menimbulkan efek gagasan pengulangan untuk menegaskan keadaan yang telah terjadi dan emosi lebih nyata.

Nilai moral dalam kumpulan puisi Ayat-Ayat Api sudah sangat bagus. Nilai moral dalam puisi tersebut mengandung hal yang positif sehingga dapat diambil hikmah dan pesan yang 
disampaikan. Nilai moral yang ada dapat dijadikan pembelajaran yang baik untuk kehidupan sehari-hari di lingkungan masyarakat sesuai dengan norma. Norma dan aturan yang berlaku terkait dengan berkata jujur, berbuat benar, berlaku adil, dan berani yang harus diperjuangkan dan ditegakkan untuk kepentingan individu maupun bersama. Hasil simpulan nilai moral pada kumpulan puisi Ayat-Ayat Api diperoleh data meliputi 4 aspek yaitu terdapat nilai moral berkata jujur, nilai moral lainnya adalah berbuat benar, berlaku adil, dan berani. Dari data hasil temuan tersebut peneliti menyimpulkan aspek nilai moral yang dominan ditemukan yaitu berkata jujur, berbuat benar, dan berani, tujuannya agar pembaca mencontoh atau menerapkan aspek nilai moral tersebut dalam kehidupan sehari-hari. Mengingat pergaulan remaja saat ini sudah tidak memedulikan nilai moral dalam pergaulannya. Dengan memahami dan mengerti isi kumpulan puisi tersebut, pembaca dapat menambah wawasan dan pengetahuan untuk dijadikan contoh di kehidupan sehari-hari. Adanya nilai moral yang baik akan menjadikan hidup lebih baik dan terarah.

Berdasarkan hasil wawancara dengan ahli sastra dan guru Bahasa Indonesia kelas $\mathrm{X}$ di SMA Negeri Gondangrejo, Karanganyar didapatkan hasil bahwa relevansinya sangat baik sekali, sehingga layak untuk dijadikan sebagai bahan ajar bahasa Indonesia yang baik. Kumpulan puisi ini dapat menambah wawasan dan pengetahuan yang baik bagi peserta didik dan pendidik/pengajar. Hasil temuan gaya bahasa bahkan nilai moral pada kumpulan puisi Ayat-Ayat Api relevan dijadikan bahan ajar Bahasa Indonesia di SMA khususnya pada KD 3.17 tentang menganalisis unsur pembangun puisi. Hal tersebut sesuai dengan kriteria bahan ajar yang menjadi acuan penilaian yaitu meliputi kriteria materi/isi, penyajian, dan kebahasaannya. Buku kumpulan puisi Ayat-Ayat Api karya Sapardi Djoko Damono dapat digunakan sebagai bahan ajar puisi terutama pada KD yang telah disebutkan di atas dalam pembelajaran Bahasa Indonesia, buku tersebut juga banyak mengandung pesan yang baik, tidak ada unsur negatif dan hal-hal yang berbau SARA. Namun, perlu adanya seleksi terhadap beberapa gaya bahasa yang dirasa sulit bagi kalangan siswa SMA serta perlu diarahkannya nilai moral pada kumpulan puisi tersebut.

\section{REFERENSI}

Agni, B. (2009). Sastra Indonesia Lengkap: Pantun, Puisi, Majas, Peribahasa, Kata, Mutiara. Jakarta: Hi-Fest Publishing.

Aminuddin. (2009). Pengantar Apresiasi Puisi Karya Sastra. Bandung: Sinar Baru Algensindo.

Arsanti, M. (2014). Pengembangan Bahan Ajar Mata Kuliah Penulisan Kreatif Bermuatan Nilai-Nilai Pendidikan Karakter Religius Bagi Mahasiswa Prodi PBSI, FKIP, UNISSULA. Skripsi Tidak Dipublikasikan. Pendidikan Bahasa dan Sastra Indonesia, FKIP, Univeristas Islam Sultan Agung Semarang.

Damono, S. D. (2017). Ayat-Ayat Api.

Jakarta: Gramedia Pustaka Utama.

Departemen Pendidikan Nasional. (2006). Pedoman Memilih dan 
Menyusun Bahan Ajar. Jakarta: Direktorat Sekolah Menengah Pertama, Direktorat Jendral Manajemen Pendidikan Dasar dan Menengah, Departemen Pendidikan Nasional.

(2008). Pengembangan Bahan Ajar dan Media. Jakarta: Direktorat Sekolah Menengah Pertama, Direktorat Jendral Manajemen Pendidikan Dasar dan Menengah, Departemen Pendidikan Nasional.

Djojosuroto, K. (2005). Puisi, Pendekatan, dan Pembelajaran. Bandung: Nuansa.

Endraswara, S. (2011). Metodologi Penelitian Sastra. Yogyakarta: CAPS.

Harjono, N. (2012). Kajian Stilistika Puisi-Puisi Chairil Anwar sebagai Sarana Pembelajaran Apresiasi Sastra. Scholaria, 2 (1), 22-38.

Hasanah, U. (2017). Nilai Moral Dalam Saq Al-Bambu Karya Sa'ud AlSan'usi. Adabiyyat: Jurnal Bahasa dan Sastra, 1 (1), $112-$ 138.

Hidayah, N. K. (2012). Nilai-nilai Moral dalam Novel Negeri Lima Menara Karya A. Fuadi. Skripsi Tidak Dipublikasikan. Pendidikan Bahasa Sastra Indonesia, dan Daerah, Universitas Negeri Malang.

Hudi, I. (2017). Pengaruh Pengetahuan Moral terhadap Perilaku Moral Pada Siswa SMP Negeri Kota Pekan baru Berdasarkan Pendidikan Orangtua. Jurnal Moral Kemasyarakatan, 2 (1), 30-44.

Husen, D. P., Wartiningsih, A., \& Syahrani, A. (2016). Analisis Gaya Bahasa dalam Slogan
Makanan Ringan di Pontianak Kalimantan Barat. Jurnal Bahasa dan Sastra, 1 (1), 1-8.

Keraf, G. (2008). Diksi dan Gaya Bahasa. Jakarta: Gramedia Pustaka Utama. 